\title{
エ事記録
}

\section{新型スリップフォーム工法による 複合構造高橋脚の施工}

馬淵勝美 ${ }^{* 1} \cdot$ 市川博康 ${ }^{* 2} \cdot$ 奥田幸男 ${ }^{* 3} \cdot$ 加藤敏明 ${ }^{* 4}$

\begin{abstract}
概 要 従来の高橋脚の施工は多量の鉄筋の組立て, 型枠足場の施工に多大な労力と時間を要することや作業安全性の 確保が課題であった。「ハイブリッド・スリップフォーム工法」は構造を簡素化した「鋼管・コンクリート複合構造」に 新しい夕イプのスリップフォーム工法を合理的に組み合わせて, 経済的に大幅な省力化亡工期短縮を可能にする工法であ る。本工法の初適用例である大分自動車道横道橋の橋脚工事では, 在来工法に比べて工期が 4 割減, 省力化で 3 割減とい う結果を達成した。今回の成果に基づき， 50 ～ $100 \mathrm{~m}$ 級高橋脚の経済施工への展開を図っている。

キーワード : 複合構造, 高橋脚, スリップフォーム, ジャンピングフォーム
\end{abstract}

\section{1.はじめに}

最近のコンクリート構造物に対する技術開発は, 経済 性との調和をとりながら省力化や工期短縮あるいは作業 安全性向上などの諸目的を達成することが重要となって きている。

本報告における山間部高架橋などの高橋脚を対象とし

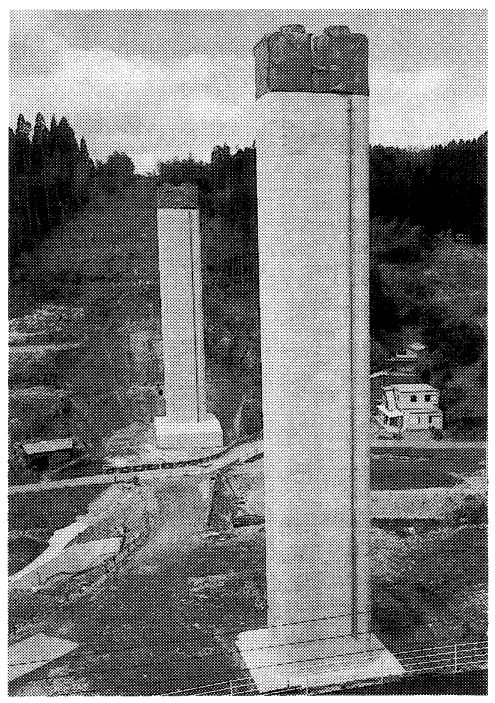

写真-1 横道橋橋脚

*1 まぶち・かつみ/日本道路公団 福岡建設局 日田工事事 務所 工事長

*2 2 いちかわ・ひろやす / 日本道路公団 福岡建設局 構造技 術課 課長代理

$* 3$ おくだ・ゆきお/侏大林組 建築生産本部特殊工法部 課 長

*4 4 かう・としあき／侏大林組 土木技術本部設計第二部 課長代理
た場合, 運搬条件の厳しさや狭い施工ヤード等, 高橋脚 特有の施工条件を考慮して新工法を開発する必要があ る。このような施工条件下では，プレキャスト化より も，コンクリートミキサ車で運搬して現場で型枠に流し 込むという場所打ちコンクリート本来の特徴を生かすこ とが経済的に有利となろう。このとき, 従来の橋脚構造 に替えて施工のたやすい構造を用い，その構造に適した 材料および施工法を合理的に組み合わせれば，過大なイ ニシャルコストを投じることなく，大幅な省力化や工期 短縮を可能にするものと考えられる。

大分自動車道横道橋橋脚は，上記の観点から開発した 鋼管・コンクリート複合構造と新しい形式の型枠工法を 組み合わせた「ハイブリッド・スリップフォーム工法」 による初の施工例である（写真-1）。

2. 鋼管・コンクリート複合構造橋脚の採 用

高橋脚構造として一般に用いられてきている鉄筋コン クリート中空箱型断面（図一1）は，長年の経験を経て おり, 力学面，材料面からみた合理性は否定できない。

一方，これを施工面からみると鉄筋の組立てやコンク リート打設等の作業は, 高度な熟練と労働者の多大な負 担によって支えられており，現在の熟練労働者不足や高 齢化は適正な工程管理や品質管理を次第に困難にしつつ ある。

本工法で開発した鋼管・コンクリート複合構造橋脚 は，施工を容易にするとともに欠陥が生じにくい構造と するために配筋を極力簡素化している。本構造は, 図 -2 に示すように大口径の鋼管を断面内部に, 縦筋を外 周 1 段のみ配置し，この縦筋外周に $\mathrm{PC}$ 鋼より線を帯鉄 筋としてスパイラル状に巻き付ける基本構造になってい 
る。

本鋼管・コンクリート複合構造では，一般部における 鋼管とコンクリートとの発生付着応力度の照査および鋼 管上下端のリブ付鋼管定着によって鋼管とコンクリート の一体化挙動を保証し, 断面計算は RC 方式を採用し ている。累加強度方式とするためには，鋼管相互の一体 化連結が必要となり，作業性・経済性が低下する点を考 慮して上記の方式を採用した。

せん断力に対する設計においては，せん断耐力に鋼管 がどのように寄与するか不明な点が残っているため, $\mathrm{RC}$ 断面のみでせん断力を受け持つ安全側の設計を行っ た。鋼管のせん断耐力への寄与については今後の検討課 題としている。

鋼管と PC 鋼より線帯鉄筋を用いた本複合構造の特長 を表-1 に示す。

本構造の開発に際して,
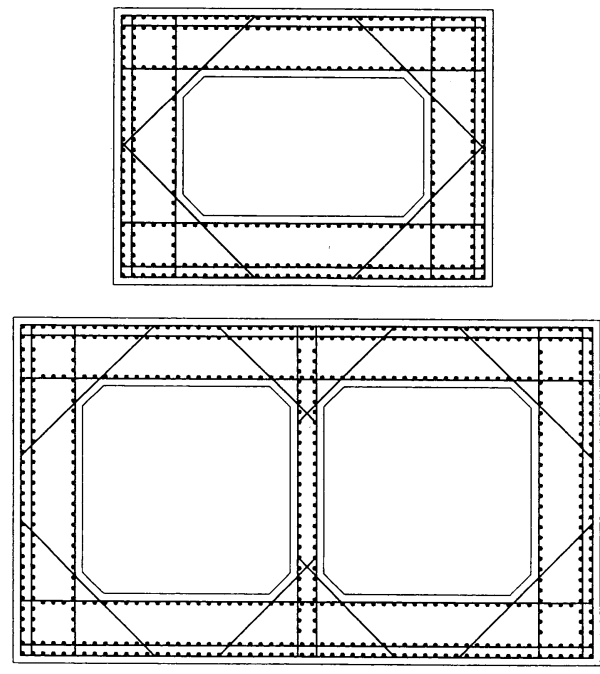

図-1＼cjkstart鉄筋コンクリート中空箱型断面例
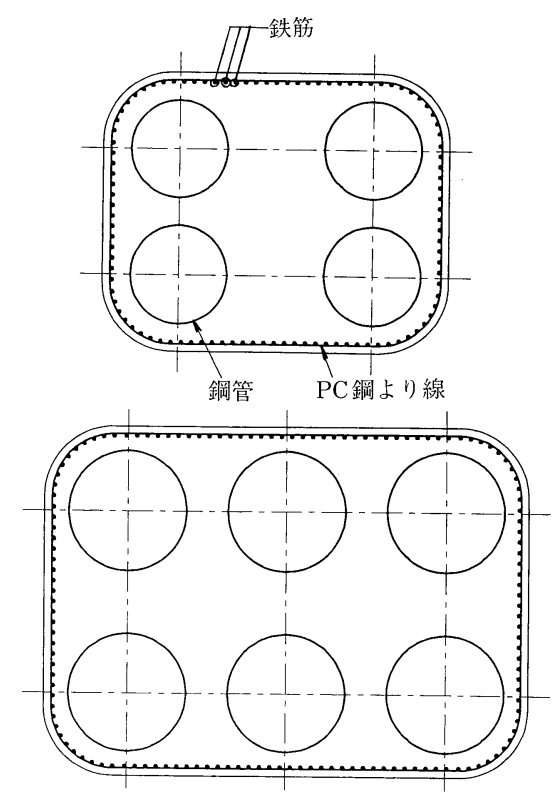

図-2＼cjkstart鋼管・コンクリート複合構造断面例

表-1 使用材料の特長

\begin{tabular}{|c|c|}
\hline 使用材料 & 特長または効果 \\
\hline $\begin{array}{c}\text { 龬 管 } \\
\text { (JIS 規格鋼管) }\end{array}$ & $\begin{array}{l}\text { • 鉄筋の代替使用により, 鉄筋組立のプレ } \\
\text { ファブ化を図る。 } \\
\text { • 単体剛性が高く, 架設時の施工性, 建込精 } \\
\text { 度が良い。 } \\
\text { • 溶接性が良い（自動溶接が容易である)。 } \\
\text { •内型枠, 鉄筋の保持, 作業足場の設置およ } \\
\text { びスリップフォームのつり上げなど省力 } \\
\text { 化, 精度向上, 安全性向上に寄与する。 } \\
\text { ・開放された断面となり, コンクリート打 } \\
\text { 設, 充てんが容易である。 }\end{array}$ \\
\hline $\mathrm{PC}$ 鋼より線 & $\begin{array}{l}\text { ・帯鉄筋の組立を省力化，機械化することが } \\
\text { できる。 } \\
\text { ・じん性能向上に寄与する。 }\end{array}$ \\
\hline
\end{tabular}

Application of New Slipform Method For Hybrid Structural High Pier

By K. Mabuchi, H. Ichikawa, Y. Okuda and T. Kato

Concrete Journal, Vol. 33, No. 4, pp. 55 61, April 1995

Synopsis The conventional construction method of high pier has issues which needs large number of labor force and re-bar assembling, forming, scaffolding time. "Hybrid-Slipform Method"-A rational conbination of a new concept of structural design and effective integration of construction techniques which enable the construction of high pier to be fast track using a reduced rabor force. In the first application of this method at Yokomiti Bridge, the time required for site operation was almost $60 \%$ and the labor force was $70 \%$ compared with the conventional construction scheme. In consequence, the new construction method would be applicable for construction of 50 to $100 \mathrm{~m}$ high pier with economical base.

Keywords : hybrid structure, high pier, slipform, jampingform 
1）外側リブ付鋼管を用いた簡便な定着構造に対する 付着強度試験

2）横道橋橋脚をプロトタイプとした橋脚模型の水平 加力試験

を実施し，耐震性を確認している。

また，本複合構造のじん性に富む構造特性を生かす設 計法の取りまとめを現在行っているところである。

3. 新型スリップフォーム工法

\section{1 従来の型枠工法}

高橋脚の施工法のポイントは足場および型枠工法に集 約されるが，一般に高さ $40 \mathrm{~m}$ を超える高橋脚に対して は足場と型枠が一体となって上昇するセルフクライミン グ工法 (ジャンピングフォーム工法) が採用されている。

本工法は上昇方法に多少の差はあるものの, 多数の施 工実績によりほぼ完成された工法となっている。すなわ ち, 1 リフト高 $3 \sim 5 \mathrm{~m}$ を 7 日ないし 14 日程度で施工し ており, 作業員数之作業日数は鉄筋組立, 型杂の上昇 組立・解体でほぼ決まっている。したがって, 大幅な省 力化之工期短縮を実現するためには，これら各々の作業 を根本的に改革していく必要がある。

一方, スリップフォーム工法は急速施工法として高層 煙突, 高架水槽等で施工実績が多いものの, わが国で高 橋脚施工に本格的に用いられてきていない。この理由 は, (1)多量の鉄筋組立がスリップフォームの施工性を損 ねていること，(2)表面仕上げに問題があること, (3)昼夜 連続施工が週休 2 日をめざす労働環境に合わないこと, などによるものであると考えられる。

\section{2 新型スリップフォーム工法}

「ハイブリッド・スリップフォーム工法」では，まず 第 1 に「鋼管・コンクリート複合構造」の採用により, 大部分の鉄筋の簡素化, 先行組立を行っているため, そ の日のコンクリート打設リフト分の鋼より線帯筋を巻き 付けるだけで鉄筋組作業が完了する。これによってス リップフォーム工法の施工速度を生かして, 1 日（8 時 間労働) で $2.4 \mathrm{~m} \sim 3.0 \mathrm{~m}$ 以上の施工高が可能となる。

第 2 に表面仕上げの向上, 養生対策およびコンクリー 卜の昼夜連続打設を解決するため, フレッシュコンク リートと接するせき板を残して支保工部のみスリップ アップする構造とした。残したせき板は回収し転用する。

第 3 にスリップフォーム装置の上昇機構は, 先行建込 鋼管からつり降ろした PC 鋼より線を介してジャッキ アップする方法を採用している。この方法は, 安定した 引き上げ荷重を得ることができるとともに，鋼管をガイ ドに利用して出来形精度を確保できるという利点があ る。

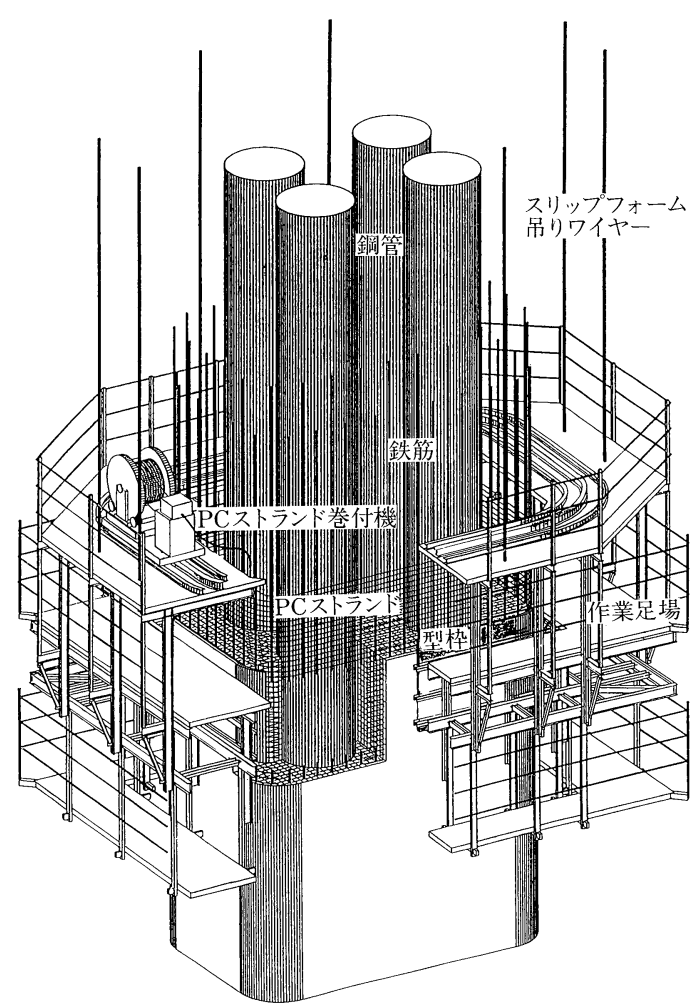

図-3ハイブリッド・スリップフォーム工法の概念図

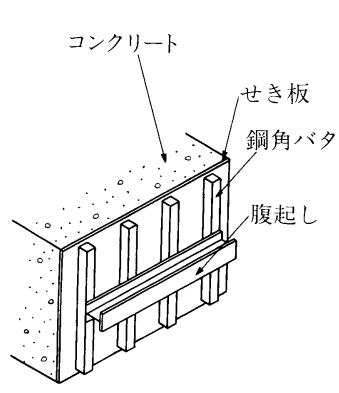

(1) コンクリート打設

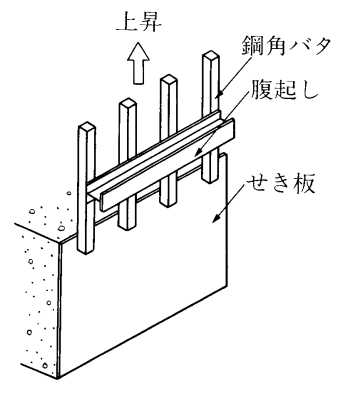

(2) 型枠支保工の上昇

\section{図-4 型枠の上昇方法}

この新型スリップフォームは，コンクリートに負担を 与えず若材齢で脱型できるという点でスリップフォーム としての機能を持ち, 表面仕上げの良さ, 十分な養生が できること，および断続的な型枠移動ができるという点 でジャンピングフォームの機能を持つ。

\section{4. 工 事 概 要}

本工法を適用した横道橋工事概要を以下に示す。また 橋りょう一般図および橋脚構造図をそれぞれ図 -5 およ び図-6に，工事数量を表-2に示す。

路 線 名: 大分自動車道

架橋位置 : 大分玖珠郡九重町 


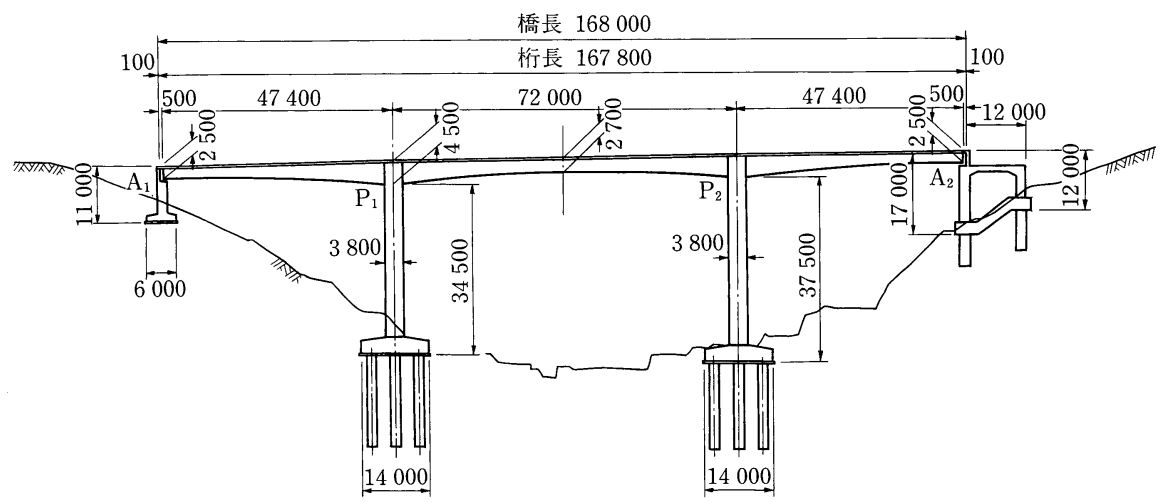

図-5 横道橋一般図

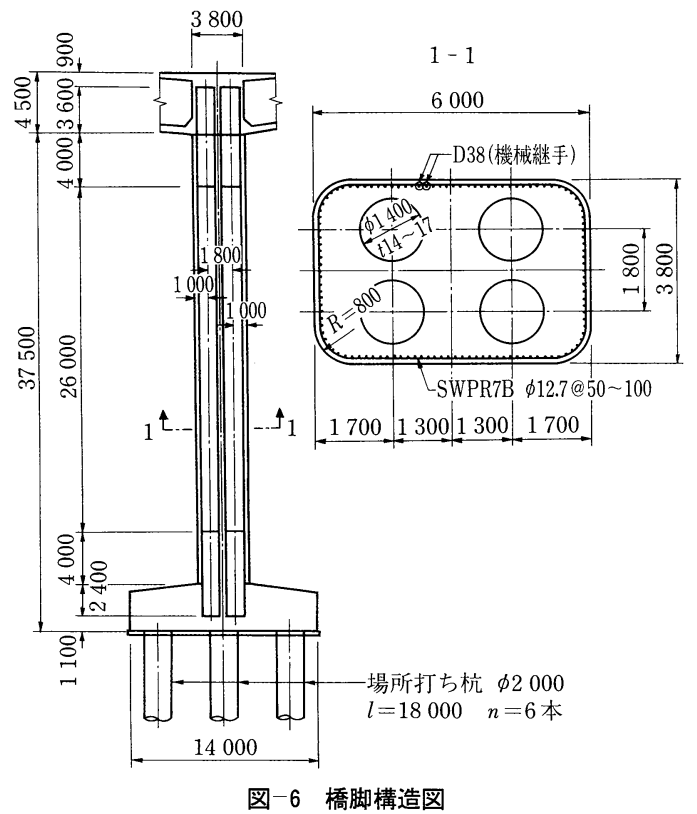

図-6 橋脚構造図
表 -2 横道橋橋脚工事数量

\begin{tabular}{|c|c|c|c|}
\hline 程 & 別 & 仕 & 数 \\
\hline \multicolumn{2}{|c|}{ コンクリート } & $\sigma \mathrm{ck}=300 \mathrm{kgf} / \mathrm{cm}^{2}$ & $1140 \mathrm{~m}^{3}$ \\
\hline 鉄 & 箭 & SD 345 (D 38) & $81 \mathrm{t}$ \\
\hline 鋼 & 管 & SKK $490(\phi 1400)$ & $170 \mathrm{t}$ \\
\hline \multicolumn{2}{|c|}{$\mathrm{PC}$ 鋼より線 } & SWPR 7 B $\phi 12.7$ & $14 \mathrm{t}$ \\
\hline
\end{tabular}

橋 格: 一等橋 $(\mathrm{TL}-20, \mathrm{TT}-43)$

構造形式 : PC 3 径間連続ラーメン橋

橋 長 : $168 \mathrm{~m}$

支間 割 : $47.4 \mathrm{~m}+72.0 \mathrm{~m}+47.4 \mathrm{~m}$

幅 員: $9.0 \mathrm{~m}$

5. 施 工

\section{1 施工順序}

橋脚高により多少の変更はあるものの基本的な施工順 序は図-7に示すとおりである。

1）最下段の鋼管をフーチング内に設置・固定する。

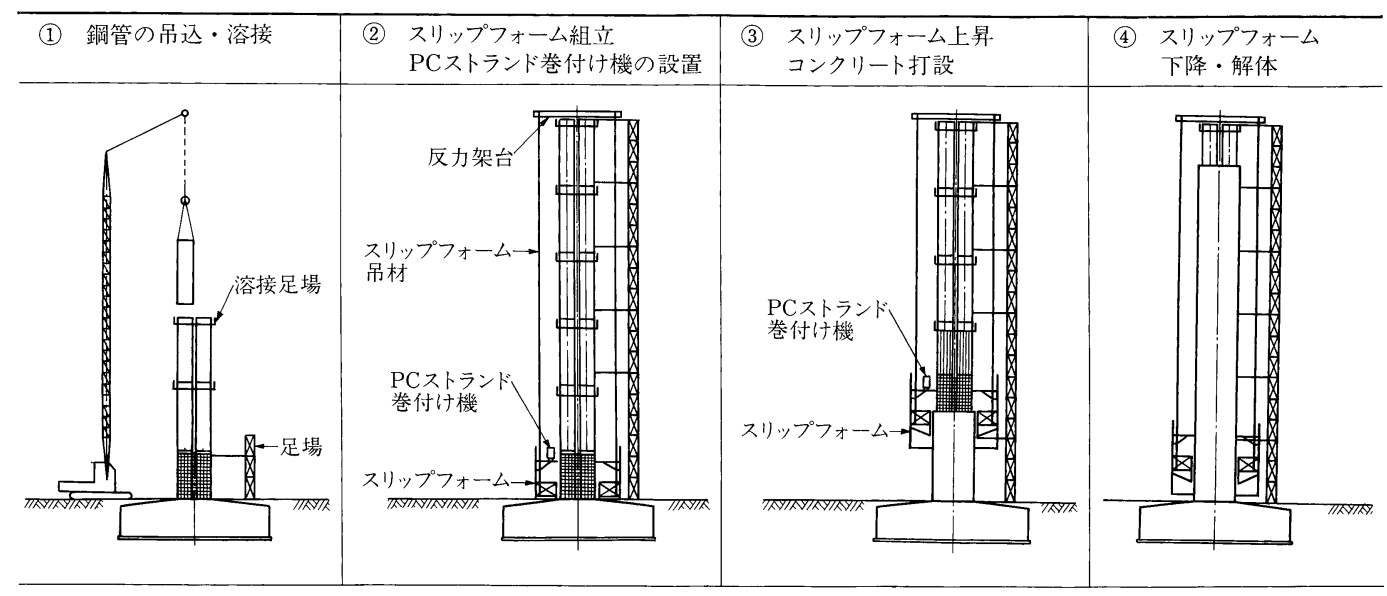

図-7 施 工 順 序 
フーチング内の鉄筋の組立て, $\mathrm{PC}$ 鋼より線の初期 巻付けを完了したのち, フーチングコンクリートを 打設する。鋼管の建込み，溶接を繰り返してながら 最上段まで鋼管を建込む（写真-2）。

2）鋼管頂部にスリップフォーム反力架台とつり材を 設置する。スリップフォーム装置を組立て，最上部 足場に PC 鋼より線巻付け機を設置する（写真一 3)。

3） 1 日の作業の中で, $\mathrm{PC}$ 鋼より線の巻付け, ス リップフォームの上昇，コンクリート打設を繰返 し，橋脚を施工する（写真 $-4 ） 。$

4）橋脚施工完了後，スリップフォーム装置と地上ま で下降し, 解体する (写真 -5$)$ 。

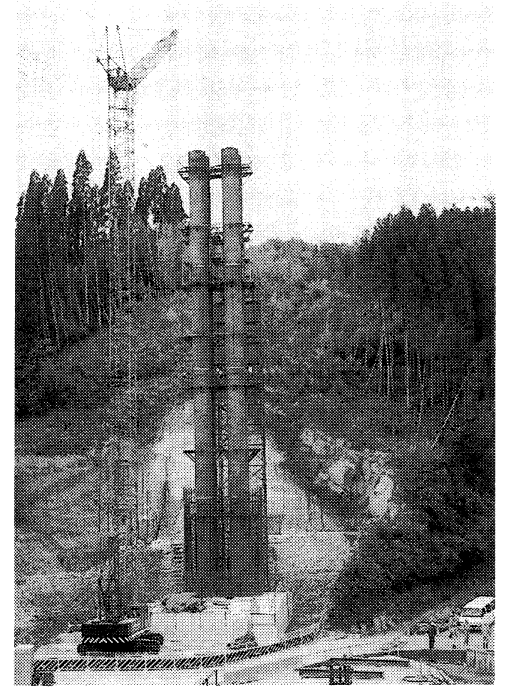

写真-2 鋼管建込み状況

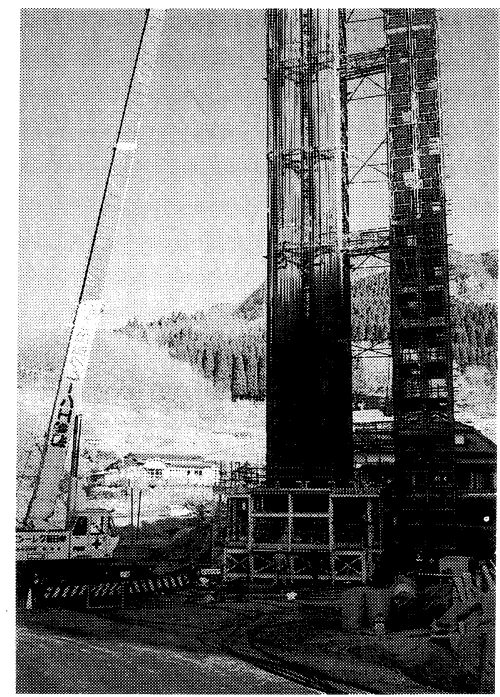

写真-3 スリップフォーム装置の組立
なお，橋脚高が $100 \mathrm{~m}$ 級になる場合，鋼管の自立高 さを $50 \mathrm{~m}$ 程度とし，コンクリート打設を先行する。次 に上部残りの鋼管を建込んだ後, 同じ要領で上半部のコ ンクリートを打設する方法を採用する。

\section{2 フーチング内鋼管の据付けと $\mathrm{PC}$ 鋼より線の初 期巻付け}

（1）鋼管の据付け

$\mathrm{H}$ 鋼架台上に鋼管を建込み，水平，垂直精度を チェックした後, 溶接固定した（図-8, 写真-6)。

(2) $\mathrm{PC}$ 鋼より線の初期巻付け

フーチング内およびフーチング上約 $5 \mathrm{~m}$ の範囲は巻 付け機械が使用できないため，アウタープルスタンドか

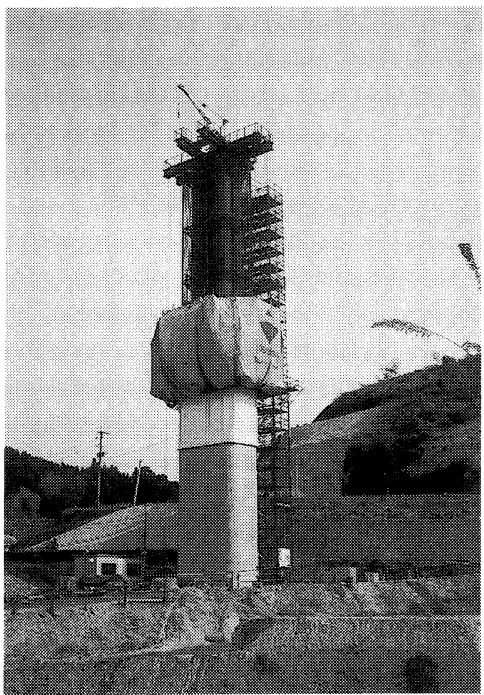

写真-4 スリップフォーム上昇状況

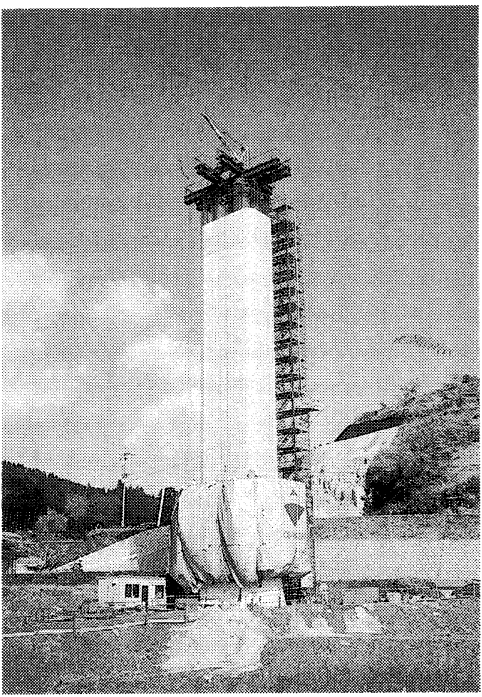

写真-5 スリップフォーム下降状況 
ら $\mathrm{PC}$ 鋼より線の引出しを行い，人力により巻付けを 行った（写真 -7 )。

\section{3 鋼管の建込みと溶接}

\section{（1）鋼管の建込み}

鋼管のつり込み長さおよび重量は，運搬条件および使 用クレーム能力から長さ $10 \mathrm{~m}$, 重量 $6 \mathrm{t} \sim 7 \mathrm{t}$ とした。

鋼管の仮固定および精度確保のため 1 段ごとにブレー スをとった，ブレース部材は風に対する安全性を検討し て決定した。

（2）鋼管継手部の溶接

鋼管に取り付けた鋼製足場を利用して，鋼管を建込ん だ後一段ごとに溶接を行った。

風による溶接欠陥を防ぐため防風対策を行うととも に，比較的風による影響を受けにくいインナーシールド 溶接（半自動）を採用した。品質検査は施工試験，外観

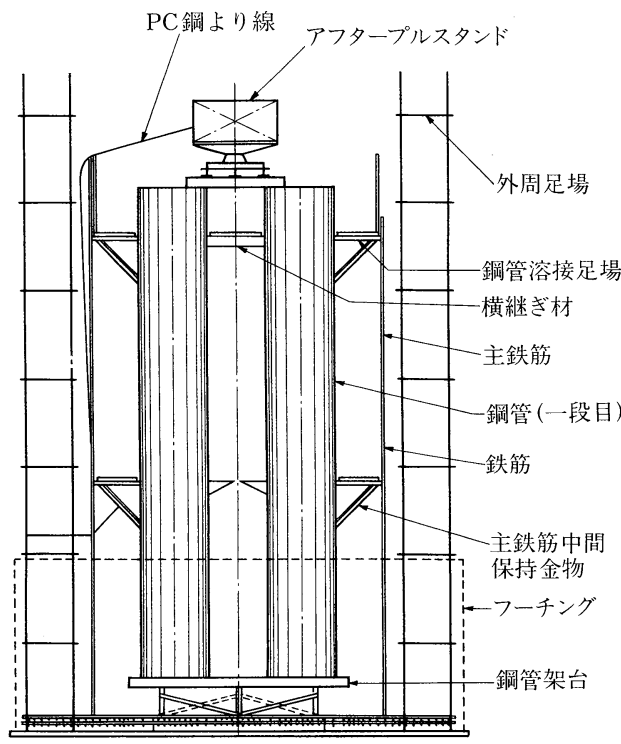

図-8 鋼管の据付け

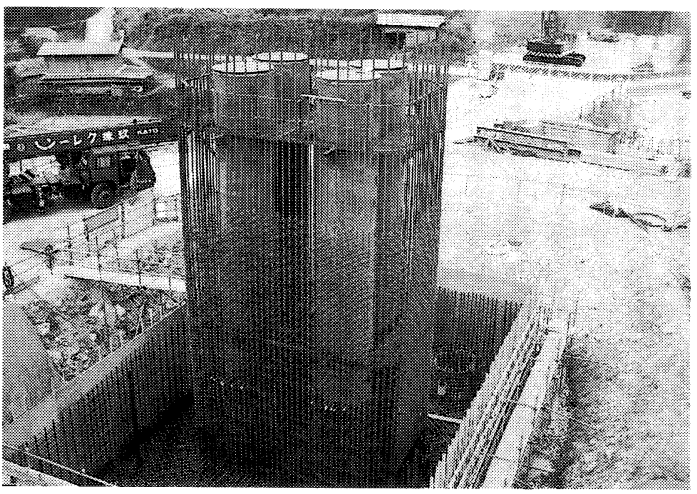

写真 $-6 \quad P C$ 鋼より線の初期巻付け
検査，超音波探傷検査により実施した。

\section{$5.4 \mathrm{PC}$ 鋼より線巻付けエ}

$\mathrm{PC}$ 鋼より線を使用した帯鉄筋の組立ては，スリップ フォーム最上段足場に設置した巻付機により機械化し た。この巻付機（写真-8）は自走台車がレール上を走 行し，連動してコイルから鋼より線を引き出す機能を持 つ。

$\mathrm{PC}$ 鋼より線の緹筋への取付けは，専用の固定金具を 用いて人力により行った。1 リフト $1.8 \mathrm{~m}$ の巻付けに要 した時間は約 1.5 時間であった。

\section{5 コンクリート打設および養生}

コンクリートの压送は橋脚高が 30 数 $\mathrm{m}$ であり, 特殊 な処理は行わず，スランプ $8 \mathrm{~cm}$ 圧送した。

打設時期が寒中コンクリートとなったため，凝結開始 時間が遅延し，コンクリート打設当日にスリップフォー

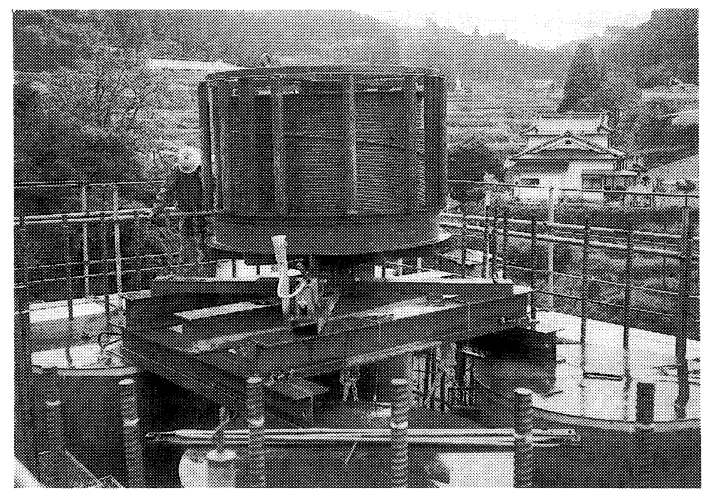

写真-7 アウタープルスタンド

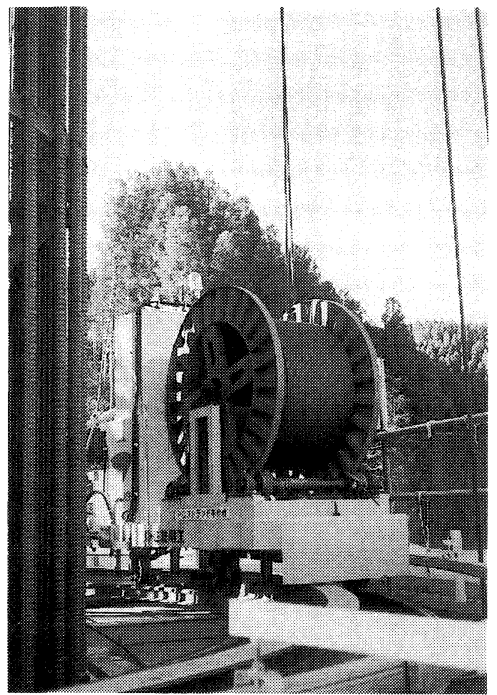

写真-8 PC 鋼より線巻付機 
表 -3 横道橋橋脚施工工程

\begin{tabular}{|c|c|c|c|c|c|c|c|c|}
\hline \multirow{3}{*}{ 項 目 } & & & \multicolumn{4}{|c|}{ 平成 5 年 } & \multicolumn{2}{|c|}{ 平成 6 年 } \\
\hline & & & 9月 & 10月 & 11月 & 12月 & 1月 & 2 月 \\
\hline & & & 1020 & 1020 & 1020 & 1020 & 1020 & 1020 \\
\hline \multirow{3}{*}{ P1 橋脚 } & \multicolumn{2}{|c|}{ フーチング工 } & -1 & & & & & \\
\hline & \multirow{2}{*}{ 橋脚工 } & 鋼管建込 & & 1 & & & & \\
\hline & & スリップフォーム & & & \multicolumn{2}{|c|}{$\frac{1+1}{1-1}$} & & \\
\hline \multirow{3}{*}{ P2 橋脚 } & \multicolumn{2}{|c|}{ フーチング工 } & & \multicolumn{2}{|c|}{$\frac{1}{1+1}$} & & & \\
\hline & \multirow{2}{*}{ 橋脚工 } & 鋼管建込 & & & 1 & & & \\
\hline & & スリップフォーム & & & & & \multicolumn{2}{|c|}{11} \\
\hline
\end{tabular}

么脱型必要強度を得ることができない状沉となった。し たがって，打設翌日に脱型する本工法はこの問題点を解 決する有効な方法である。また前にも述べたとおり，作 業効率からも 1 日 1 回コンクリート打設, 翌日上昇の方 が良いと考えられる。

寒中養生については, スリップフォーム装置外周を シートで覆い, 電気暖房 (エアコン) による保温を実施 した。また, 残存したせき板による保水, 保温も効果的 であったが，残存期間を 1 日としたため, 温度応力によ るヘアクラックが部材厚の小さい部分に発生した。今後 寒中コンクリートの施工に際しては, せき板の残存期間 をさらに長くすること。また, 内部コアコンクリートの 温度上昇抑制等を総合的に対策を実施していきたい。

\section{6 工 程}

フーチングおよび脚柱部の施工工程を表 -3 に示す。 横道橋橋脚の場合は, 橋脚高が $31 \mathrm{~m}$ および $34 \mathrm{~m}$ の 2 基の橋脚に対して, 試算によれば約 6 割の工期で施工で きた。本工法が工期短縮を実現する理由は，鋼管の先行 建込みとスリップフォームの施工速度にある。したがっ て，この特長を生かす施工条件は，(1) 2 基以上の橋脚を 施工すること，(2)橋脚高が $40 \mathrm{~m}$ 以上で，高くなるほど 効果がでる。本工法の経済性は，作業人員および仮設機 材を増やすことなく工程を短縮できることによって発揮
されると言える。

\section{6. おわりに}

横道橋橋脚の施工が本工法の初適用にもかかわらず施 工性，安全性において将来の発展性に対する評価を各方 面からいただいた。その後, 技術検討会を中心に一層の 経済性の追求や施工面での改善を加え, 在来方法とコス 卜競争ができるところまできている。特に施工費ではす でに在来工法に対してコストダウンが可能となってお り，材料費の低減を中心に検討を進めているところであ る。

また，イニシャルコスト以外に耐震性の向上, 作業安 全性の向上，あるいは大幅な短工期による経費節減効果 などの本工法のもつ付加価值をコスト評価に加えていく 必要もあると考えられる。

最後に本工事の実施に際し, 多大なご協力とご指導を いただいた関係各位に深く感謝いたします。

参 考 文 献

1) 水田, 馬淵, 大内, 入沢 : 鋼管・コンクリート複合構造 高橋脚の開発（その 1)一スパイラルリブ付き鋼管の付 着試験一土木学会第 49 回年次学術講演会概要集

2) 市川, 忽那, 大内, 小畠：鋼管・コンクリート複合構造 高橋脚の開発（その 2) 一橋脚模型の水平加力試験一土 木学会第 49 回年次学術講演会概要集

\section{コンクリート構造物の補修工法研究委員会報告書（ II）}

A 4 判・153 ページ/定価 5000 円 (税込)，会員特価 4500 円（税込）/送料 430 円

-申込先：(社) 日本コンクリート工学協会・管理課「書籍販売係」

干102 千代田区麦町 5-7 TBR 708 号／電話 (03) 3263-1571（担当：宇野)

〈申込方法〉書籍名・送付先を明記のうえ，前金（現金書留）にてお申込み下さい。 